\title{
Penerapan Asuhan Keperawatan Jiwa Pada Ny.P Dengan Gangguan Persepsi Sensori : Halusinasi
}

\section{Sururin Maudhunah}

sururinm@gmail.com

\section{BAB 1}

\section{PENDAHULUAN}

\subsection{Latar Belakang}

Skizofrenia merupakan kondisi psikotik yang berpengaruh terhadap area fungsi individu, termasuk berpikir, berkomunikasi, menerima, menafsirkan kenyetan, merasakan dan menunjukkan emosi serta penyakit kronis yang ditandai dengan pikiran kacau, delusi, halusinasi, dan perilaku (Pardede, Simanjuntak \& Laia, 2020). Skizofrenia merupakan gangguan mental beret dan kronis yang menyerang 20 juta orang di seluruh dunia (WHO, 2019), Sedangkan di Indonesia, Prevalensi Skizofrenia yaitu 1,7 per mil penduduk etau sekitar 400 ribu orang (Riskesdas, 2013). Sedangkan Hasil Riskesdas (2018) didapatkan estimasi prevalensi orang yang pernah menderita skizofrenia di Indonesia sebesar 1,8 per 1000 penduduk.

Skizofrenia adalah bentuk gangguan jiwa yang sering dijumpai dan multifaktorial, perkembangannya dipengaruhi oleh factor genetik dan lingkungan serta ditandai dengan gejala positif, negatif dan defisit kognitif. Peristiwa yang penuh stres, akan mengaktifkan aksis hipotalamus hipofisisadrenal dan merangsang pelepasan berbagai neurotransmitter otak, terutama dopamine dan norepinefrine, kejadian ini juga dianggap sebagai faktor terjadinya skizofrenia (Rinawati \& Alimansur, 2016).

Sebagian besar penderita gangguan jiwa adalah penderita skizofrenia. Penderita ini mendominasi jumlah penderita gangguan jiwa, yaitu 99\% dari seluruh gangguan jiwa dirumah sakit Prevalensi penderita skizofrenia di Indonesia adalah 0,3-1\% dan dapat timbul pada usia 18-45 tahun, bahkan ada 
yang timbul pada penderita usia 11-12 tahun. Apa bila penduduk Indonesia berjumlah dua ratus juta jiwa, maka di perkirakan sekitar juta juta jiwapenduduk menderita skizofrenia (Pardede \& Purba, 2020).

Diperkirakan empat ratus juta orang diseluruh dunia mengalami gangguan jiwa, sekitar $10 \%$ orang dewasa akan mengalami gangguan jiwa saat ini dan $25 \%$ penduduk diperkirakan akan mengalami gangguan jiwa pada usia tertentu selama hidupnya. Gangguan jiwa mencapai 13\% dari penyakit secara keseluruhan dan kemungkinan akan berkembang menjadi 25\% ditahun 2030.Gangguan jiwa tersebut berhubungan dengan bunuh diri setiap tahunnya akibat gangguan jiwa, hingga sekarang penanganan penderita gangguan jiwa belum memuaskan sehingga terjadi peningkatan seperti yang terlihat diatas, sesuai dari data yang telah dipaparkan bahwa skizofrenia adalah gangguan jiwa berat yang mempunyai prevalensi paling tinggi (Pardede \& Siregar 2016).

Halusinasi merupakan persepsi yang diterima oleh panca indera tanpa adanya stimulus eksternal. Klien dengan halusinasi sering merasakan keadaan/kondisi yang hanya dapat dirasakan olehnya namun tidak dapat dirasakan oleh orang lain.Halusinasi merupakan keadaan seseorang mengalami perubahan dalam pola dan jumlah stimulasi yang diprakarsai secara internal atau eksternal disekitar denganpengurangan berlebihan, distorsi, atau kelainan berespon terhadap satiap stimulasi dan halusinasi juga merupakan perubahan dalam jumlah dan pola dari stimulasi yang diterima dan disertai dengan penurunan berlebihan distorsi atau kerusakan respon beberapa stimulasi (Aldam, \& Wardani, 2019).

Menurut Yosep (2011, dalam Anjar 2018), Halusinasi di pengaruhi oleh 2 faktor yaitu: faktor presdiposisi dan faktor presipitasi. Faktor presdiposisi adalah faktor yang mempengaruhi fungsi jenis dan jumlah sumber yang dapat dibangkitkan oleh individu untuk mengatasi stress. Faktor presdiposisi dapat meluputi faktor pengembangan, sosiokultural, biologis, psikologis dan genatik. Faktor presipitasi adalah stimulus yang di persiapkan oleh individu 
sebagai tantangan, ancaman, atau tuntutan yang memerlukan energy ekstra untuk menghadapinya. dimana di dalamnya terdapat perilaku seperti konsep diri rendah, keputusasaan, kehilangan motivasi, tidak mampu memenuhi kebutuhan spiritual (Anjar, 2018).

Berdasarkan latar belakang masalah tersebut diatas dan sebagai tugas untuk memahami keperawatan jiwa tentang maraknya kejadian halusinasi yang saya temui khususnya di Yayasan Pemenang Jiwa Medan tahun 2021, maka perlu kiranya untuk membahas masalah gangguan jiwa dengan halusinasi menggunakan Asuhan Keperawatan Jiwa dengan diagnose keperawatan Jiwa Halusinasi. Subjek didalam pembuatan askep ini berjumlah satu orang dengan pasien atas nama inisial Ny.P klien datang ke yayasan di bawa oleh keluarga klien karena awalnya klien sering membuka baju dijalanan dan sering mendengar suara suara, didiagnosa dengan Halusinasi pendengaran.

\subsection{Rumusan Masalah}

Berdasarkan latar belakang masalah tersebut maka dapat dirumuskan masalah saebagai berikut : Bagaimana Memberikan Asuhan Keperawatan Jiwa Pada Ny. P dengan Halusinasi pendengaran di Yayasan Pemenang Jiwa Sumatera.

\subsection{Tujuan}

\subsubsection{Tujuan Umum}

Untuk Mengatahui Asuhan Keperawatn Jiwa Pada Klien Dengan

Perubahan Persepsi Sensori: Halusinasi Pendengaran Di Yayasan Pemenang Jiwa Sumatera 2021

\subsubsection{Tujuan Khusus}

1. Melakukan pengkajian pada klien dengan perubahan persepsi sensori: halusinasi pendengaran

2. Membuat diagnosa keperawatan pada klien perubahan persepsi sensori : halusinasi pendengaran

3. Melakukan intervensi keperawatan kepada klien perubahan persepsi sensori:halusinasi pendengaran 
4. Melakukan tiundakan keperawatan pada klien perubahan persepsi sensori : halusinasi pendengaran

5. Mengevaluasi hasil tindakan keperawatan pada klien perubahan persepsi sensori: halusinasi pendengaran

\subsection{Manfaat}

1. Pasien

Diharapkan tindakan yang telah di ajakarkan dapat di terapkan secara mandiri untuk mengontrol halusinasi yang dialami klien dan untuk mendukung kelangsungan kesehatan pasien.

2. Yayasan Pemenang Jiwa Sumatera

Diharapkan dapat menjadi acuan dalam menanganin atau dalam memberikan pelayanan kepada pasien dengan gangguan jiwa dengan masalah Halusinasi di Yayasan Pemenang Jiwa Sumatera. 


\section{BAB 2}

\section{TINJAUAN TEORITIS}

\subsection{Konsep Halusinasi}

\subsubsection{Pengertian Halusinasi}

Halusinasi adalah keadaan seseorang mengalami perubahandalam pola danjumlah rangsangan yang dimulaisecara internal atau eksternal di sekitar dengan pengurangan, melebih-lebihkan, distorsi, atau kelainan respons terhadap setiap stimulus. Hal ini juga didukung oleh pernyataan bahwa halusinasi adalah gejala skizofrenia, halusinasipendengaran adalah yang paling sering ditemui dari 50\% -80\% (Pardede, 2019).Halusinasi adalah salah satu gejala gang- guan sensori persepsi yang dialami oleh pasien gangguan jiwa.Pasien merasakan sensasi berupa suara, penglihatan, pengecapan, perabaan, ataupenghiduan tanpa stimulus yang nyata (Zelika, \& Dermawan (2015).

Halusinasi merupakan salah satu gejalagangguan jiwa dimana pasien mengalami perubahan presepsi sensori, merasakansensasi palsu berupa suara, penglihatan, pengecapan atau perabaan. Pasien merasakan stimulus yang sebenarnya tidak ada (Aji, 2019). Halusinasi adalah salah satu gejala gangguan jiwa dimana klien mengalami perubahan persepi sensori, merasakan sensasi palsu berupa suara, penglihatan, pengecapan, perabaan dan penghiduan. Klien merasakan stimulus yang sebatul-batulnya tidak ada. Halusinasi adalah perubahan dalam jumlah atau pola stimulus yang datang disertai gangguan respon yang kurang, berlebihan, atau distorsi terhadap stimulus tersebut (Astutik, 2018).

Halusinasi didefinisikan sebagai gangguan psikosensori berbeda dari ilusi dan interpretasi delusi (yangbaginya itu identik dengan istilah Jerman delusipersepsi), yang secara khas terdiri dari persepsi tanpasebuah objek.Tiga kondisi utama terkait halusinasi adalah (1) penampakan sensoris dari pengalaman; (2) keyakinan akan realitasnya; (3) tidak adanya benda 
nyata. Di sisi lain, dia juga yakin soal halusinasi itu"Adalah sekunder dari keyakinan atau keyakinan salah (Correia, Moreira, \& Gonçalves, 2015).

\subsubsection{Etiologi}

Menurut Aldam \& Wardani, (2019), faktor-faktor yang menyebabkan klien gangguan jiwa mengalami halusinasi adalah sebagai berikut :

1. Faktor Predisposisi

a. faktor biologis yang berhubungan dengan perkembangan sistem saraf yang tidak normla,

b. Faktor psikologis seperti pola asuh orang tua, kondisi keluarga dan lingkungan,

c. Faktor sosial budaya seperti kondisi ekonomi, konflik sosial, serta kehidupan yang terisolasi disertai stres.

2. Faktor Presipitasi

a. faktor biologi yang terkait dalam gangguan komunikasi dan putaran balik otak yang mengatur proses informasi,

b. Faktor lingkungan yang mana terjadi tingkat stresor lingkungan di luar batas toleransi individu,

c. Koping yang dapat menentukan seseorang dalam mentoleransi stresor

\subsubsection{Tanda dan Gejala}

Manifestasi Klinik Halusinasi menurut Direja (2011 dalam Zelika \& Dermawan, 2015) : tanda dan gejala halusinasi pendengaran

1. data subjektif: mendengarkan suara atau kegaduhan, mendengar suara yang mengajak bercakap-cakap, mendengarkan suara yang menyuruh melakukan sesuatu yang berbahaya.

2. Data objektif: bicara atau tertawa sendiri, marah- marah tanpa sebab, mengarahkan telinga ke arah tertentu, menutup telinga 


\subsubsection{Rentang Respon Halusinasi}

Halusinasi adalah salah satu gejala gang- guan sensori persepsi yang dialami oleh pasien gangguan jiwa. Pasien merasakan sensasi berupa suara, penglihatan, pengecapan, perabaan, atau penghiduan tanpa stimulus yang nyata (Zelika \& Dermawan, 2015).

\section{Rentang Respon Halusinasi:}

$$
\begin{array}{lcc}
\multicolumn{1}{c}{\text { Pikiran logis }} & - \text { Kadang-kadang } & - \text { Waham } \\
- \text { Persepsi akurat } & \text { proses pikir } & - \text { Halusinasi } \\
- \text { Emosi konsisten } & \text { terganggu (distorsi } & - \text { Sulit berespons } \\
\begin{array}{ll}
\text { dengan } \\
\text { pengalaman }
\end{array} & \text { pikiran } & - \text { Perilaku } \\
- \text { Perilaku sesuai } & - \text { Menarik diri } & - \text { disorganisasi } \\
- \text { Hubungan sosial } & - \text { Reaksi emosi }>K & \\
\text { harmonis } & - \text { Perilaku tidak } & \\
& \text { biasa }
\end{array}
$$

\subsubsection{Jenis Halusinasi}

Menurut Stuart (2007, dalam dalam Pardede at al, 2021), jenis halusinasi antara lain :

1. Halusinasi pendengaran (auditorik) $70 \%$

Karakteristik ditandai dengan mendengar suara, teruatama suara - suara orang, biasanya klien mendengar suara orang yang sedang membicarakan apa yang sedang dipikirkannya dan memerintahkan untuk melakukan sesuatu.

2. Halusinasi penglihatan (visual) $20 \%$

Karakteristik dengan adanya stimulus penglihatan dalam bentuk pancaran cahaya, gambaran geomatrik, gambar kartun dan / atau panorama yang luas dan kompleks. Penglihatan bisa menyenangkan atau menakutkan.

3. Halusinasi penghidu (olfactory) 
Karakteristik ditandai dengan adanya bau busuk, amis dan bau yang menjijikkan seperti: darah, urine atau feses. Kadang - kadang terhidu bau harum.Biasanya berhubungan dengan stroke, tumor, kejang dan dementia.

4. Halusinasi peraba (tactile)

Karakteristik ditandai dengan adanya rasa sakit atau tidak enak tanpa stimulus yang terlihat. Contoh : merasakan sensasi listrik datang dari tanah, benda mati atau orang lain.

5. Halusinasi pengecap (gustatory)

Karakteristik ditandai dengan merasakan sesuatu yang busuk, amis dan menjijikkan, merasa mengecap rasa seperti rasa darah, urin atau feses.

6. Halusinasi cenesthatik

Karakteristik ditandai dengan merasakan fungsi tubuh seperti darah mengalir melalui vena atau arteri, makanan dicerna atau pembentukan urine.

7. Halusinasi kinesthatic

Merasakan pergerakan sementara berdiri tanpa bergerak.

\subsubsection{Fase Halusinasi}

Menurut Yusuf (2015) Fase halusinasi dibagi menjadi 4, yaitu :

\begin{tabular}{|c|c|c|}
\hline Fase halusinasi & Karakteristik & Perilaku pasien \\
\hline 1 & 2 & 3 \\
\hline $\begin{array}{l}\text { Fase I : } \\
\text { Comforting- } \\
\text { ansiatas tingkat } \\
\text { sedang, secara } \\
\text { umum, halusinasi } \\
\text { bersifat } \\
\text { menyenangkan }\end{array}$ & $\begin{array}{l}\text { Klien mengalami } \\
\text { keadaan emosi seperti } \\
\text { ansiatas, kesepian, rasa } \\
\text { bersalah, dan takut serta } \\
\text { mencoba untuk berfokus } \\
\text { pada penenangan pikiran } \\
\text { untuk mengurangi } \\
\text { ansiatas. Individu } \\
\text { mengatahui bahwa } \\
\text { pikiran dan pengalaman } \\
\text { sensori yang dialaminya } \\
\text { tersebut dapat } \\
\text { dikendalikan jika } \\
\text { ansiatasnya bias diatasi } \\
\text { (Non psikotik) }\end{array}$ & $\begin{array}{l}\text { Menyeringai atau tertawa } \\
\text { yang tidak sesuai, } \\
\text { menggerakkan bibir tanpa } \\
\text { menimbulkan suara, } \\
\text { pergerakan mata yang } \\
\text { cepat, respon verbal yang } \\
\text { lambat, diam dan dipenuhi } \\
\text { oleh sesuatu yang } \\
\text { mengasyikkan. }\end{array}$ \\
\hline
\end{tabular}




\begin{tabular}{|c|c|c|}
\hline $\begin{array}{l}\text { Fase II: } \\
\text { Condemning- } \\
\text { ansiatas tingkat } \\
\text { berat, secara } \\
\text { umum, halusinasi } \\
\text { menjadi } \\
\text { menjijikkan }\end{array}$ & $\begin{array}{l}\text { Pengalaman sensori } \\
\text { bersifat menjijikkan dan } \\
\text { menakutkan, klien mulai } \\
\text { lepas kendali dan } \\
\text { mungkin mencoba untuk } \\
\text { menjauhkan dirinya } \\
\text { dengan sumber yang } \\
\text { dipersepsikan. Klien } \\
\text { mungkin merasa malu } \\
\text { karena pengalaman } \\
\text { sensorinya dan menarik } \\
\text { diri dari orang lain. } \\
\text { (Psikotik ringan) }\end{array}$ & $\begin{array}{l}\text { Peningkatan sistem syaraf } \\
\text { otonom yang } \\
\text { menunjukkan ansiatas, } \\
\text { seperti peningkatan nadi, } \\
\text { pernafasan, dan tekanan } \\
\text { darah; penyempitan } \\
\text { kemampuan konsentrasi, } \\
\text { dipenuhi dengan } \\
\text { pengalaman sensori dan } \\
\text { kehilangan kemampuan } \\
\text { membedakan antara } \\
\text { halusinasi dengan realita. }\end{array}$ \\
\hline $\begin{array}{l}\text { Fase III: } \\
\text { Controlling- } \\
\text { ansiatas tingkat } \\
\text { berat, pengalaman } \\
\text { sensori menjadi } \\
\text { berkuasa }\end{array}$ & $\begin{array}{l}\text { Klien berhenti } \\
\text { menghentikan } \\
\text { perlawanan terhadap } \\
\text { halusinasi dan menyerah } \\
\text { pada halusinasi tersebut. } \\
\text { Isi halusinasi menjadi } \\
\text { menarik, dapat berupa } \\
\text { permohonan. Klien } \\
\text { mungkin mengalarni } \\
\text { kesepian jika } \\
\text { pengalaman sensori } \\
\text { tersebut berakhir. } \\
\text { (Psikotik) }\end{array}$ & $\begin{array}{l}\text { Cenderung mengikuti } \\
\text { patunjuk yang diberikan } \\
\text { halusinasinya daripada } \\
\text { menolaknya, kesukaran } \\
\text { berhubungan dengan orang } \\
\text { lain, rentang perhatian } \\
\text { hanya beberapa datik atau } \\
\text { menit, adanya tanda-tanda } \\
\text { fisik ansiatas berat : } \\
\text { berkeringat, tremor, tidak } \\
\text { mampu mengikuti } \\
\text { patunjuk. }\end{array}$ \\
\hline $\begin{array}{l}\text { Fase IV: } \\
\text { Conquering } \\
\text { Panik, umumnya } \\
\text { halusinasi } \\
\text { menjadi lebih } \\
\text { rumit, melebur } \\
\text { dalam } \\
\text { halusinasinya }\end{array}$ & $\begin{array}{l}\text { Pengalaman sensori } \\
\text { menjadi mengancam dan } \\
\text { menakutkan jika klien } \\
\text { tidak mengikuti perintah. } \\
\text { Halusinasi bisa } \\
\text { berlangsung dalam } \\
\text { beberapa jam atau hari } \\
\text { jika tidak ada intervensi } \\
\text { terapeutik. } \\
\text { (Psikotik Berat) }\end{array}$ & $\begin{array}{l}\text { Perilaku menyerang-teror } \\
\text { seperti panik, berpotensi } \\
\text { kuat melakukan bunuh diri } \\
\text { atau membunuh orang } \\
\text { lain, Aktivitas fisik yang } \\
\text { merefleksikan isi } \\
\text { halusinasi seperti amuk, } \\
\text { agitasi, menarik diri, atau } \\
\text { katatonia, tidak mampu } \\
\text { berespon terhadap perintah } \\
\text { yang kompleks, tidak } \\
\text { mampu berespon terhadap } \\
\text { lebih dari satu orang. }\end{array}$ \\
\hline
\end{tabular}

\subsubsection{Penatalaksanaan Medis}

Halusinasi merupakan salah satu gejala yang paling sering terjadi pada gangguan Skizofrenia. Dimana Skizofrenia merupakan jenis psikosis, adapun tindakan penatalaksanaan dilakukan dengan berbagai terapi (Hafizuddin, 2021), yaitu : 


\section{Psikofarmakologis}

Obat sangat penting dalam pengobatan skizofrenia, karena obat dapat membantu pasien skizofrenia untuk meminimalkan gejala perilaku kekerasan, halusinasi, dan harga diri rendah. Sehingga pasien skizofrenia harus patuh minum obat secara teratur dan mau mengikuti perawatan.

a. Haloperidol (HLD)

Obat yang dianggap sangat efektif dalam pengelolaan hiperaktivitas, gelisah, agresif, waham, dan halusinasi.

b. Chlorpromazine (CPZ)

Obat yang digunakan untuk gangguan psikosis yang terkait skizofrenia dan gangguan perilaku yang tidak terkontrol

c. Trihexilpenidyl (THP)

Obat yang digunakan untuk mengobati semua jenis parkinson dan pengendalian gejala ekstrapiramidal akibat terapi obat.

1. Dosis

a) Haloperidol $3 \times 5 \mathrm{mg}$ (tiap 8 jam) intra muscular.

b) Clorpromazin $25-50 \mathrm{mg}$ diberikan intra muscular setiap 6-8 jam sampai keadaan akut teratasi.

2. Dalam keadaan agitasi dan hiperaktif diberikan tablet:

a) Haloperidol 2x1,5 - 2,5 mg per hari.

b) Klorpromazin 2x100 mg per hari

c) Triheksifenidil $2 \times 2 \mathrm{mg}$ per hari

3. Dalam keadaan fase kronis diberikan tablet:
a) Haloperidol $2 \times 0,5-1 \mathrm{mg}$ perhari
b) Klorpromazin 1x50 mg sehari (malam)
c) Triheksifenidil 1-2x2 mg sehari
d) Psikosomatik

2. Terapi kejang listrik (Electro Compulsive Therapy), yaitu suatu terapi fisik atau suatu pengobatan untuk menimbulkan kejang grand mal secara artifisial dengan melewatkan aliran listrik melalui elektroda yang dipasang pada satu atau dua temples pada pelipis. Jumlah tindakan yang dilakukan merupakan rangkaian yang 
bervariasi pada setiap pasien tergantung pada masalah pasien dan respon terapeutik sesuai hasil pengkajian selama tindakan. Pada pasien Skizofrenia biasanya diberikan 30 kali. ECT biasanya diberikan 3 kali seminggu walaupun biasanya diberikan jarang atau lebih sering. Indikasi penggunaan obat: penyakit depresi berat yang tidak berespon terhadap obat, gangguan bipolar di mana pasien sudah tidak berespon lagi terhadap obat dan pasien dengan bunuh diri akut yang sudah lama tidak mendapatkan pertolongan.

\section{Psikoterapi}

Membutuhkan waktu yang relatif lama, juga merupakan bagian penting dalam proses terapeutik. Upaya dalam psikoterapi ini meliputi: memberikan rasa aman dan tenang, menciptakan lingkungan terapeutik, memotivasi klien untuk dapat mengungkapkan perasaan secara verbal, bersikap ramah, sopan, dan jujur terhadap klien.

\subsubsection{Komplikasi}

Halusinasi dapat menjadi suatu alasan mengapa klien melakukan tindakan perilaku kekerasan karena suara-suara yang memberinya perintah sehingga rentan melakukan perilaku yang tidak adaptif. Perilaku kekerasan yang timbul pada klien skizofrenia diawali dengan adanya perasaan tidak berharga, takut dan ditolak oleh lingkungan sehingga individu akan menyingkir dari hubungan interpersonal dengan orang lain,komplikasi yang dapat terjadi pada klien dengan masalah utama gangguan sensori persepsi: halusinasi, antara lain: resiko prilaku kekerasan, harga diri rendah dan isolasi sosial (Keliat, 2014). 


\subsection{Konsep Dasar Keperawatan Halusinasi}

\subsubsection{Pengkajian}

Pengkajian adalah proses untuk tahap awal dan dasar utama dari proes keperawatan terdiri drai pengumpulan data dan perumusan kebutuhan atau masalah klien. Data yang dikumpulkan melalui data biologis, psikologis, sosial dan spiritual. Pengelompokkan data pengkajian kesehatan jiwa, dapat berupa faktor presipitasi, penilaian terhadap stressor, sumber koping, dan kemampuan yang dimiliki. Saat melakukan pengkajian dengan menggunakan pendekatan kepada pasien dan keluarga.Pengkajian pada pasien dilakukan menggunakan metode wawancara, diskusi dan observasi (Aji, 2019).

\subsubsection{Diagnosa Keperawatan}

Menurut Andri at al(2019), ada beberapa diagnosa keperawatan yang sering ditemukan pada klien dengan halusinasi, yaitu:

a. Gangguan sensori persepsi halusinasi

b. Isolasi Sosial

c. Resiko tinggi perilaku kekerasan (diri sendiri, orang lain, lingkungan dan verbal).

\subsubsection{Intervensi Keperawatan}

Perencanaan diberikankepada klien difokuskan pada tujuan umum untuk menyelesaikan masalah dengan perencanaan seperti: klien mampu melakukan terapi aktivitas dengan cara demonstrasi, rolepay dan independen yang baik dan benar. Diharapkan klien dapat mengenal halusinasi yang bersifat alamiah, pasien dapat mengontrol halusinasinya secara mandiri, pasien dapat menjaga agar halusinasinya berkurang / tidak mudah muncul (Libriatanti, 2019).

\subsubsection{Implementasi Keperawatan}

Penerapan keperawatan yang diberikan dalam penelitian ini merupakan tindakan yang diberikan kepada klien untuk membantu mengurangi intensitas munculnya halusinasi dan mengendalikan halusinasi yang terjadi di alam.Metode yang digunakan adalah dengan memberikan peragaan, peran dan 
kemandirian tentang terapi senam agar dapat mengurangi dan mengendalikan halusinasi dengan baik (Libriatanti, 2019).
a. Bina hubungan saling percaya (BHSP)
b. Identifikasi, waktu, frekuensi, situasi, respon klien terhadap halusinasi
c. Melatih klien mengontrol halusinasi dengan cara menghardik
d. Melatih klien mengontrol halusinasi dengan cara patuh minum obat
e. Melatih klien dengan cara bercakap-cakap
f. Melatih klien mengontrol halusinasi dengan cara melaksanakan kegiatan terjadwal.

\subsubsection{Evaluasi Keperawatan}

Evaluasi adalah proses yang berkelanjutan untuk menilai efek dari tindakan keperawatan pada klien yang telah dilakukan. Evaluasi dilakukan sesuai dengan tindakan keperawatan yangtelah dilaksanakan. Evaluasi dapat dibagi dua yaitu evaluasi proses dan evaluasi formatif,dilakukan setiap selesai melaksanakan tindakan evaluasi hasil atau sumatif dilakukan denganmembandingkan respon klien pada tujuan yang telah ditentukan sebelumnya (Widuri \& Widodo, 2016). 


\section{BAB 3}

\section{TINJAUAN KASUS}

Ruang rawat : Yayasan Pemenang Jiwa Medan

Tanggal Pengkajian : 02-27 Marat 2021

\subsection{Identitas Klien}

$\begin{array}{ll}\text { Inisial } & : \text { Ny. P } \\ \text { Jenis Kelamin } & : \text { Perempuan } \\ \text { Umur } & : \text { 35 tahun } \\ \text { Agama } & : \text { Kristen Protestan } \\ \text { Status } & : \text { Lajang } \\ \text { Informan } & : \text { Pengawas yayasan dan Komunikasi dengan klien } \\ \text { Tanggal pengkajian } & : \text { 02-27 Marat 2021 }\end{array}$

\subsection{Riwayat}

Klien pernah masuk rumah sakit dan dibawa ke Poli Jiwa karna pasien sering berbicara sendiri dan Alasan klien datang ke RSJ klien sering berbicara sendiri, mendengar atau melihat sesuatu, suka berjalan tanpa tujuan, membanting peralatan dirumah, menarik diri. tatapi klien hanya bertahan selama seminggu di rumah sakit lalu di pulangkan dengan alasan keluarga tidak memiliki biaya yg cukup untuk melanjutkan perawatan di Poli Jiwa.

Masalah Keperawatan: Gangguan Persepsi Sensori: Halusinasi Pendengaran

\subsection{Faktor Predisposisi}

Klien sebelumnya pernah mengalami gangguan jiwa \pm 23 tahun yang lalu dan keluarga percaya bahwasa pasien tersebut adalah penyakit yang diguna-guna oleh orang yang tidak suka dengan pasien tersebut, sehingga keluarga tidak membawa kerumah sakit hanya dengan pengobatan orang pintar (dukun). dan Ny. P tidak pernah memiliki suami,dulu Ny. P pernah berpacaran, namun ternyata semenjak putus dengan pacarnya Ny. Pmenjadi suka bicara sendiri dan marah- marah dengan keluarga.

\subsection{Fisik}


Klien tidak memiliki keluhan fisik, saat dilakukan pemeriksaan tanda-tanda vital, didapatkan hasil TD : 120/80 mmHg ; N : 80x/i ; S : 35oC ; P : 20x/i. Klien memiliki tinggi badan $154 \mathrm{~cm}$ dan berat badan $67 \mathrm{Kg}$.

\subsection{Psikososial}

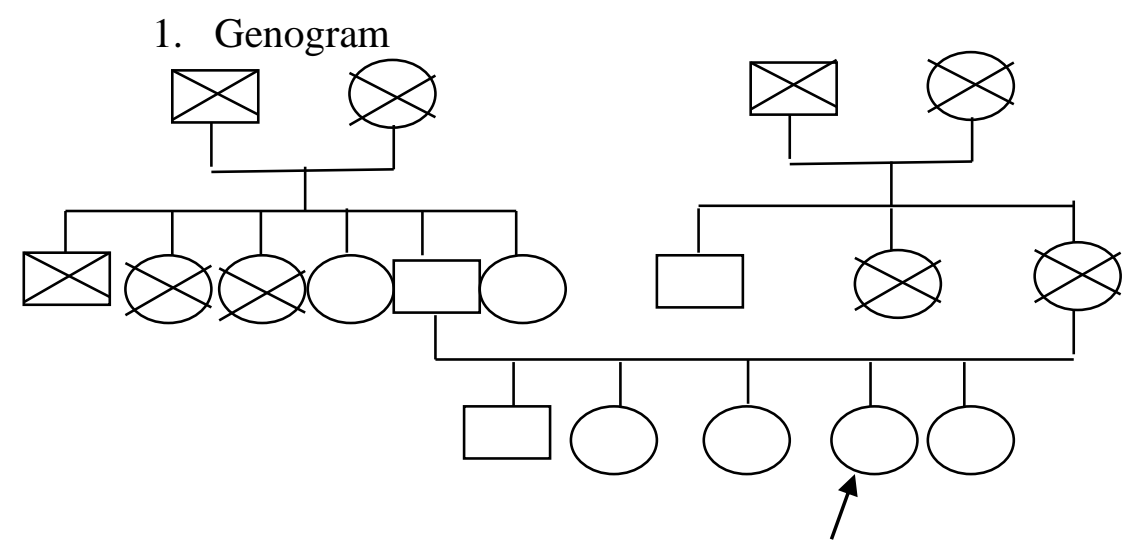

Jekaskan : pasien adalah anak ke empat dari 5 bersaudara ayahnya masih hidup sedangkan ibu nya telah meninggal dunia. Klien belum menikah.

Katerangan :

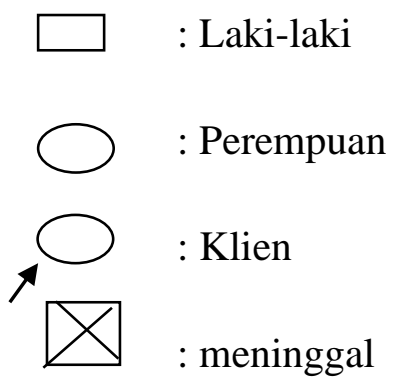

\section{Konsep Diri}

a. Gambaran Diri

Klien menyukai seluruh tubuhnya dan tidak ada yang cacat

b. Identitas

Klien anak ke 4 dari 5 bersaudara, klien hanya lulusan SMA yang saat ini tidak memiliki pekerjaan

c. Peran 
Klien berperan sebagai anak

d. Ideal diri

Klien merasa malu karena klien dirawat di yayasan pemenang jiwa dan ingin cepat pulang ke rumah.

e. Harga diri

klien mengatakan merasa malu berada di yayasan pemenang jiwa dan merasa bosan.

3. Hubungan sosial

a. Orang yang berarti :

Klien mengganggap bahwa keluarganya adalah orang yang sangat berarti dalam hidupnya, terutama orangtuanya.

b. Peran serta dalam kegiatan kelompok/masyarakat :

Klien selalu mengikuti kegiatan di yayasan tersebut. Klien mengatakan tidaksuka bergaul dengan teman-teman yang ada di yayasan pemenang jiwa, dia lebih suka menyendiri.

Masalah keperawatan: Isolasi sosial

c. Hambatan dalam berhubungan dengan orang lain :

Klien mengatakan mempunyai hambatan dalam berhubungan dengan orang lain, karena klien adalah tipe orang yang tidak suka bergaul dengan orang lain, klien lebih suka menyendiri dikamar

\section{Spiritual}

a. Nilai dan Keyakinan

Pasien beragama Kristen Protestan dan pasien mempercayai agamanya

b. Kegiatan ibadah

Klien ikut melakukan ibadah selama dirawat.

\subsection{Status Mental}

1. Penampilan

Klien berpenampilan bersih, dan rapi .

2. Pembicaraan 
Klien masih dapat menjawab pertanyaan perawat dengan lambat namun dapat dipahami.

3. Aktivitas Motorik

Klien terlihat tenang.

4. Suasana perasaan

Klien sering merasa cemas,karna sering mendengar bisikan dari telingga kiri dan kanan.

Masalah keperawatan : Gangguan Persepsi Sensori : Halusinasi Pendengaran

5. Afek

Afek klien labil, mudah emosi, mudah marah.

Masalah keperawatan : Risiko perilaku kekerasan

6. Interaksi selama wawancara

Klien kooperatif, ada kontak mata, tapi pandangan terlihat kosong pada lawan bicara, dan klien terlihat tenang dan mengikuti instruksi.

7. Persepsi

Sering mendengar suara-suara disiang hari sedang sendiri dan istirahat.

Masalah keperawatan : Gangguan Persepsi Sensori : Halusinasi Pendengaran

8. Proses Pikir

Klien mampu menjawab apa yang ditanya dengan baik.

9. Isi pikir

Klien kadang mengatakan bahwa dirinya yang berhak mengatur keadaan di dalam rumah dan klien sering marah pada keluarga dan katika marah klien mau berteriak dan melemparkan pakaian pakaian yg ada di sekitarnya.

Masalah Keperawatan : Resiko Prilaku Kekerasan

10. Tingkat kesadaran

Klien tidak mengalami gangguan orientasi, klien mengenali waktu, orang dan tempat. 
11. Memori

Klien mampu menceritakan kejadian di masa lalu dan yang baru terjadi,dan mampu mengulang pertemuan yang dilakukan terapi.

12. Tingkat konsentrasi berhitung

Klien mampu berkonsentrasi dalam perhitungan sederhana tanpa bantuan orang lain.

13. Kemampuan penilaian

Klien dapat membedakan hal yang baik dan yang buruk.

14. Daya tilik diri

Klien mengatahui bahwa dia sering marah,dan sering mendengar suara-suara

\subsection{Mekanisme Koping}

Klien mengalami mekanisme koping adaptif yaitu klien dapat berbicara baik dengan orang lain dan berkooperatif

\subsection{Masalah Psikososial dan Lingkungan}

Klien mengatakan jarang mengikuti kegiatan di lingkungan rumah karna tidak suka bersosialisasi

\subsection{Pengatahuan Kurang Tentang Gangguan Jiwa}

Klien mengatahui tentang gangguan jiwa yang di alaminya dan obat yang dikonsumsinya.

\subsection{Aspek Medik}

Diagnosa Medik : Skizofernia Paranoid

Terapi Medik :

1. Resperidone $1 \times 1$

2. Depakot $2 \times 1$ 
3.11 Analisa Data

\begin{tabular}{|c|c|c|}
\hline No & Data & Masalah Keperawatan \\
\hline 1 & $\begin{array}{l}\text { Subjektif: } \\
\text { klien mengatakan katika } \\
\text { siang hari sering mendengar } \\
\text { suara bising yang membuat } \\
\text { dia takut, cemas dan emosi } \\
\text { katika mendengar suara } \\
\text { bisikan dari kiri dan kanan } \\
\text { telinganya. Dan keluarga } \\
\text { mengatakan klien sering } \\
\text { berbicara sendiri. } \\
\text { Objektif : } \\
\text { klien tanpak kelihatan cemas } \\
\text { dan katakutan, dan terkadang } \\
\text { menutup telinganya dan } \\
\text { banyak suara yg didengarnya } \\
\text { yg selalu mengganggu nya }\end{array}$ & $\begin{array}{c}\text { Gangguan Persepsi } \\
\text { Sensori : Halusinasi } \\
\text { Pendengaran }\end{array}$ \\
\hline 2 & $\begin{array}{l}\text { Subjektif : } \\
\text { keluarga klien mengatakan } \\
\text { klien sering marah-marah dan } \\
\text { jika marah pasien mengamuk } \\
\text { dan mengangkat tempat tidur } \\
\text { klien tersebut. } \\
\text { Objektif: } \\
\text { Pandangan klien terlihat } \\
\text { kosong dan pandangan sinis }\end{array}$ & $\begin{array}{c}\text { Risiko Perilaku } \\
\text { Kekerasan }\end{array}$ \\
\hline
\end{tabular}




\begin{tabular}{|l|l|l|}
\hline 3 & $\begin{array}{l}\text { Subjektif : } \\
\text { Klien merasa sulit untuk } \\
\text { memulai pembicaraan kepada } \\
\text { orang lain }\end{array}$ & Isolasi Sosial \\
Objektif : & $\begin{array}{l}\text { Klien tampak menyendiri, } \\
\text { dan berbicara lambat dan } \\
\text { suka menghindar }\end{array}$ & \\
\hline
\end{tabular}

3.12 Pohon Masalah

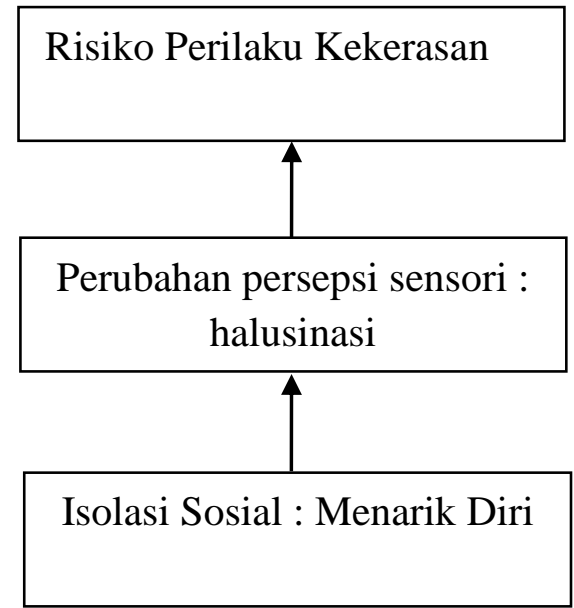

\subsection{Diagnosa Keperawatan}

1. Gangguan persepsi sensori : Halusinasi

2. Risiko Perilaku Kekerasan

3. Isolasi social : Menarik Diri 
3.14 Intervensi Keperawatan

\begin{tabular}{|c|c|c|c|}
\hline $\begin{array}{l}\text { Diagnosa } \\
\text { Kenerawatan }\end{array}$ & Tujuan & Kriteria Hasil & Intervensi \\
\hline \multirow[t]{4}{*}{$\begin{array}{l}\text { gangguan } \\
\text { persepsi ; } \\
\text { Halusinasi } \\
\text { Pendengaran }\end{array}$} & $\begin{array}{l}\text { Kliendapatmembi } \\
\text { na hubungan } \\
\text { saling percaya }\end{array}$ & $\begin{array}{lr}\text { klien } & \text { mampu } \\
\text { mempercayai perawat, } \\
\text { dan klien } \quad \text { bisa } \\
\text { menerima semua apa } \\
\text { yang telah diajarkan } \\
\text { dan } & \text { diberikan } \\
\text { masukkan } & \text { kepada } \\
\text { klien } & \end{array}$ & $\begin{array}{l}\text { a. Membina hubungan } \\
\text { saling percaya dengan } \\
\text { cara (menjelaskan } \\
\text { maksud dan tujuan } \\
\text { interaksi, jelaskan } \\
\text { tentang kontrak yang } \\
\text { akan dibuat, beri rasa } \\
\text { aman dan sikapempati) } \\
\text { b. Diskusikan bersamaklien } \\
\text { tentang halusinasi yang } \\
\text { didengarkan } \\
\text { (penyebab, tanda dan } \\
\text { gejala, perilaku yang } \\
\text { muncul dan akibatdari } \\
\text { perilaku tersebut). }\end{array}$ \\
\hline & $\begin{array}{l}\text { klien mampu } \\
\text { mengontrol } \\
\text { Halusinasi }\end{array}$ & $\begin{array}{l}\text { Klien mampu } \\
\text { mengidentifikasikan } \\
\text { halusinasi, dank lien } \\
\text { mampu melakukan } \\
\text { mengontrol } \\
\text { halusinasi dengan } \\
\text { menghardik }\end{array}$ & $\begin{array}{l}\text { Sp } 1 \\
\text { a. Mengidentifikasi isi, } \\
\text { frekuensi,waktu terjadi, } \\
\text { situasi, pencatus, } \\
\text { perasaan dan respon } \\
\text { halusinasi } \\
\text { b. Mengontrol halusinasi } \\
\text { dengan menghardik }\end{array}$ \\
\hline & $\begin{array}{l}\text { klien mmapu } \\
\text { mengontrol } \\
\text { halusinasi }\end{array}$ & $\begin{array}{l}\text { Klien mampu } \\
\text { mengendalikan } \\
\text { halusinasi dengan } \\
\text { minum obat }\end{array}$ & $\begin{array}{l}\text { Sp 2: } \\
\text { Mengontrol Halusinasi } \\
\text { dengan minum obat secara } \\
\text { teratur }\end{array}$ \\
\hline & $\begin{array}{l}\text { klien mampu } \\
\text { mengontrol } \\
\text { halusinasi dank } \\
\text { lien mampu } \\
\text { bersosialisasi } \\
\text { dengan orang lain }\end{array}$ & $\begin{array}{l}\text { klien mampu dan } \\
\text { dapat mengontrol } \\
\text { halusisasi dengan } \\
\text { berbicara dengan } \\
\text { kluarga dna orang lain }\end{array}$ & $\begin{array}{l}\text { SP 3: } \\
\text { Mengontrol halusinasi } \\
\text { dengan bercakap-cakap } \\
\text { dengan orang lain. }\end{array}$ \\
\hline
\end{tabular}




\begin{tabular}{|c|c|c|c|}
\hline & dan keluarga & & \\
\hline & $\begin{array}{l}\text { klien mampu } \\
\text { mengontrol } \\
\text { halusinasi }\end{array}$ & $\begin{array}{l}\text { klien mampu } \\
\text { melakukan kegiatan } \\
\text { dan mengontrol } \\
\text { halusinasi }\end{array}$ & $\begin{array}{l}\text { SP } 4 \text { : } \\
\text { Mengontrol halusinasi } \\
\text { dengan melakukan legiatan } \\
\text { terjadwal. }\end{array}$ \\
\hline $\begin{array}{l}\text { Risiko } \\
\text { Perilaku } \\
\text { Kekerasan }\end{array}$ & $\begin{array}{l}\text { Klien dapat } \\
\text { mengendalikan } \\
\text { perilaku } \\
\text { kekerasan }\end{array}$ & $\begin{array}{l}\text { 1. Klien mampu } \\
\text { menyebutkan dan } \\
\text { menredemonstrasi } \\
\text { kan caramengontrol } \\
\text { perilaku kekerasan } \\
\text { dengan cara relaksasi } \\
\text { nafas dalam dan } \\
\text { pukul bantal } \\
\text { 2. Klien } \\
\text { mampumengendalikan } \\
\text { perilaku kekerasan } \\
\text { dengan minum obat } \\
\text { 3. Klien paham dan } \\
\text { mampu } \\
\text { menyampaikan } \\
\text { amarah dengan cara } \\
\text { berbicara dengan baik } \\
\text { 4. Klien paham dan } \\
\text { mampu } \\
\text { mengendalikan risiko } \\
\text { perilaku kekerasan } \\
\text { dengan caraberibadah }\end{array}$ & $\begin{array}{l}\text { Sp 1: } \\
\text { Latih klien melakukan } \\
\text { cara mengontrol } \\
\text { Kemarahan: } \\
\text { 1. Ajarkan tehnik relaksasi } \\
\text { nafas dalam } \\
\text { 2. Pukul bantal } \\
\text { Sp 2: } \\
\text { Bantu klien mengontrol } \\
\text { perilaku kekerasan pasien } \\
\text { dengan minum obat secara } \\
\text { teratur } \\
\text { Lakukan SP } 3 \text { pasien risiko } \\
\text { perilaku kekerasan : Ajarkan } \\
\text { kepada klien bicara yang } \\
\text { baik bila sedang marah. Ada } \\
\text { tiga cara: } \\
\text { • Meminta dengan } \\
\quad \text { baik tanpamarah } \\
\text { - Menolak } \\
\quad \text { denganbaik } \\
\text { Mengungkapkan } \\
\quad \text { perasaan kesal } \\
\text { Lakukan SP 4 pasien risiko } \\
\text { perilaku kekerasan : } \\
\text { Diskusikan bersama klien } \\
\text { cara mengendalikan risiko } \\
\text { cara beribadah. }\end{array}$ \\
\hline Isolasi Sosial & $\begin{array}{l}\text { Pasien mampu : } \\
\text { 1. Membina } \\
\text { hubungan } \\
\text { saling percaya } \\
\text { 2. Menyadari } \\
\text { penyebab } \\
\text { isolasi social }\end{array}$ & $\begin{array}{l}\text { 1. Mampu membina } \\
\text { hubungan saling } \\
\text { percaya di tandai } \\
\text { dengan pasien } \\
\text { menunjukkan } \\
\text { ekspresi wajah } \\
\text { bersahabat, }\end{array}$ & $\begin{array}{l}\text { Sp 1: } \\
\text { Menjelaskan keuntungan } \\
\text { dan kerugian mempunyai } \\
\text { teman } \\
\text { Sp } 2 \text { : } \\
\text { Melatih klien berkenalan }\end{array}$ \\
\hline
\end{tabular}




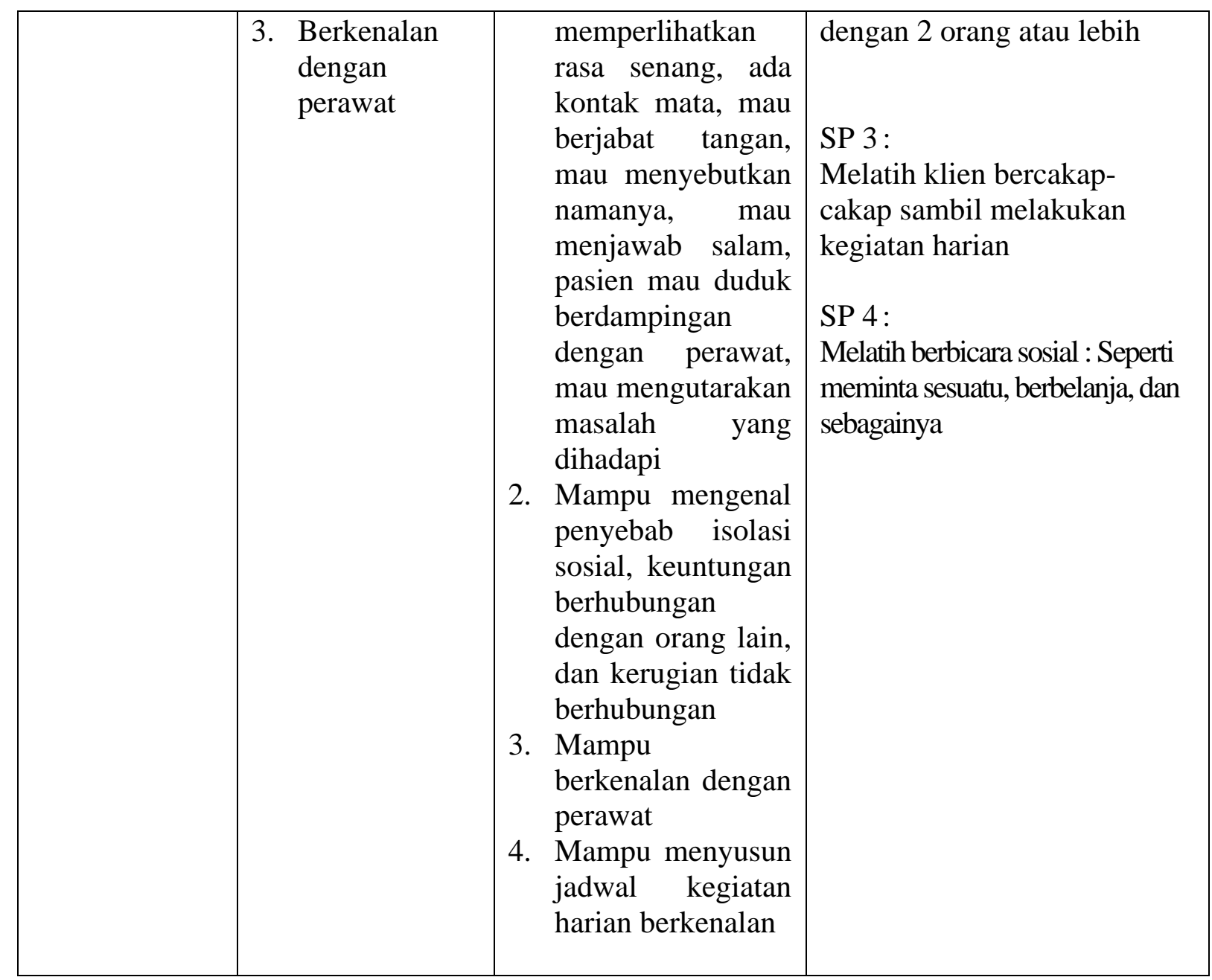

3.15. Implementasi Evaluasi Keperawatan Jiwa

\begin{tabular}{|c|c|c|}
\hline Hari/tgl & Implementasi & Evaluasi \\
\hline $\begin{array}{l}\text { Selasa, } 09 \\
\text { Maret } 2021 \\
\text { 10:30 WIB }\end{array}$ & $\begin{array}{l}\text { 1. Data: } \\
\text { Tanda dan gejala : pasien tanpat } \\
\text { katakutan dan merasa cemas } \\
\text { dengan suara yang didengarnya. } \\
\text { Kemampuan : meminum air putih } \\
\text { katika merasa cemas katika suara } \\
\text { bisikan itu datang } \\
\text { 2. Diagnosa Keperawatan } \\
\text { gangguan persepsi sensori : } \\
\text { Halusinasi pendengaran }\end{array}$ & $\begin{array}{l}\mathbf{S} \text { : klien mengatakan lebih tenang dan } \\
\text { tidak takut } \\
\mathbf{O} \text { : } \\
\text { - Klien mampu melakukan } \\
\quad \text { tindakan menghardik } \\
\text { - Klien tampak tenang } \\
\text { - Klien mau minum obat secara } \\
\text { teratur }\end{array}$ \\
\hline
\end{tabular}




\begin{tabular}{|c|c|c|}
\hline & $\begin{array}{l}\text { 3. Tindakan keperawatan: } \\
\text { Sp } 1 \text { : } \\
\text { - } \quad \text { Mengidentifikasi isi, frekuensi } \\
\text { waktu terjadi, situasi, pencatus, } \\
\text { perasaan dan respon halusinasi } \\
\text { - } \quad \text { Suara yang dating dibisikan pasien } \\
\text { membuat klien takut dan cemas, } \\
\text { dan suara itu dating siang hari } \\
\text { katika klien sedang sendiri dan } \\
\text { beristirahata dank lien selalu } \\
\text { minum air putih untuk mengatasi } \\
\text { cemasnya } \\
\text { Menyebutkan cara mengontrol } \\
\text { halusinasi dengan Menghardik. } \\
\text { Sp2 : }\end{array}$ & $\begin{array}{l}\text { A : Halusinasi Pendegaran }(+) \\
\text { P : } \\
\text { - Latihan mengontrol halusinasi } \\
\text { dengan cara menghardik } 3 x \\
\text { sehari } \\
\text { Latihan mengontrol halusinasi } \\
\text { dengan minum obat secara } \\
\text { teratur }\end{array}$ \\
\hline $\begin{array}{l}\text { Rabu, } 10 \\
\text { Maret } 2021 \\
\text { 10:00 WIB }\end{array}$ & $\begin{array}{l}\text { 1. Data: } \\
\text { Tanda dan gejala : pasien tanpat } \\
\text { katakutan dan merasa cemas }\end{array}$ & $\begin{array}{l}\mathbf{S} \text { : klien mengatakan senang bisa } \\
\text { melakukan kegiatan tersebut }\end{array}$ \\
\hline
\end{tabular}




\begin{tabular}{|c|c|c|}
\hline & $\begin{array}{l}\text { dengan suara yang didengarnya. } \\
\text { Kemampuan : meminum air putih } \\
\text { katika merasa cemas katika suara } \\
\text { bisikan itu datang } \\
\text { 2. Diagnosa Keperawatan } \\
\text { gangguan persepsi sensori : } \\
\text { Halusnasi pendengaran } \\
\text { 3. Tindakan keperawatan: } \\
\text { Sp } 3 \text { :Mengontrol halusinasi dengan } \\
\text { becakap-cakap dengan orang lain. } \\
\text { menyarankan klien untuk bercakap } \\
\text { cakap dengan keuarga, dan } \\
\text { memberitahukan kepada keluarga harus } \\
\text { mampu memndampingi dna menemani } \\
\text { pasien dalam berbicara } \\
\text { - }\end{array}$ & $\begin{array}{ll}\text { O : } & \\
& \text { Klien mampu melakukan } \\
& \text { kegiatan dngan mandiri } \\
\text { A : } & \text { halusinasi pendengaran (+) } \\
\text { P : } & \\
\text { - } & \text { Latihan mengontrol halusinasi } \\
& \text { dengan cara menghardik } 3 x \\
& \text { sehari } \\
\text { - } & \text { Latihan mengontrol halusinasi } \\
& \text { dengan minum obat secara } \\
& \text { teratur } \\
& \text { Bercakap cakap dengan orang } \\
\text { lain, (sesering mungkin) }\end{array}$ \\
\hline $\begin{array}{l}\text { Jumat, } 12 \\
\text { Maret } 2021 \\
\text { 10:30 WIB }\end{array}$ & $\begin{array}{l}\text { 1. mengevaluasi kemampuan klien } \\
\text { dalam mengontrol halusinasi } \\
\text { dengan cara menghardik } \\
\text { 2. mengevaluasi klien menontrol }\end{array}$ & $\begin{array}{l}\text { S : klien mengatakan merasan baik, dan } \\
\text { tidak cemas satelah melakukan } \\
\text { kegiatan beberapa hari ini }\end{array}$ \\
\hline
\end{tabular}




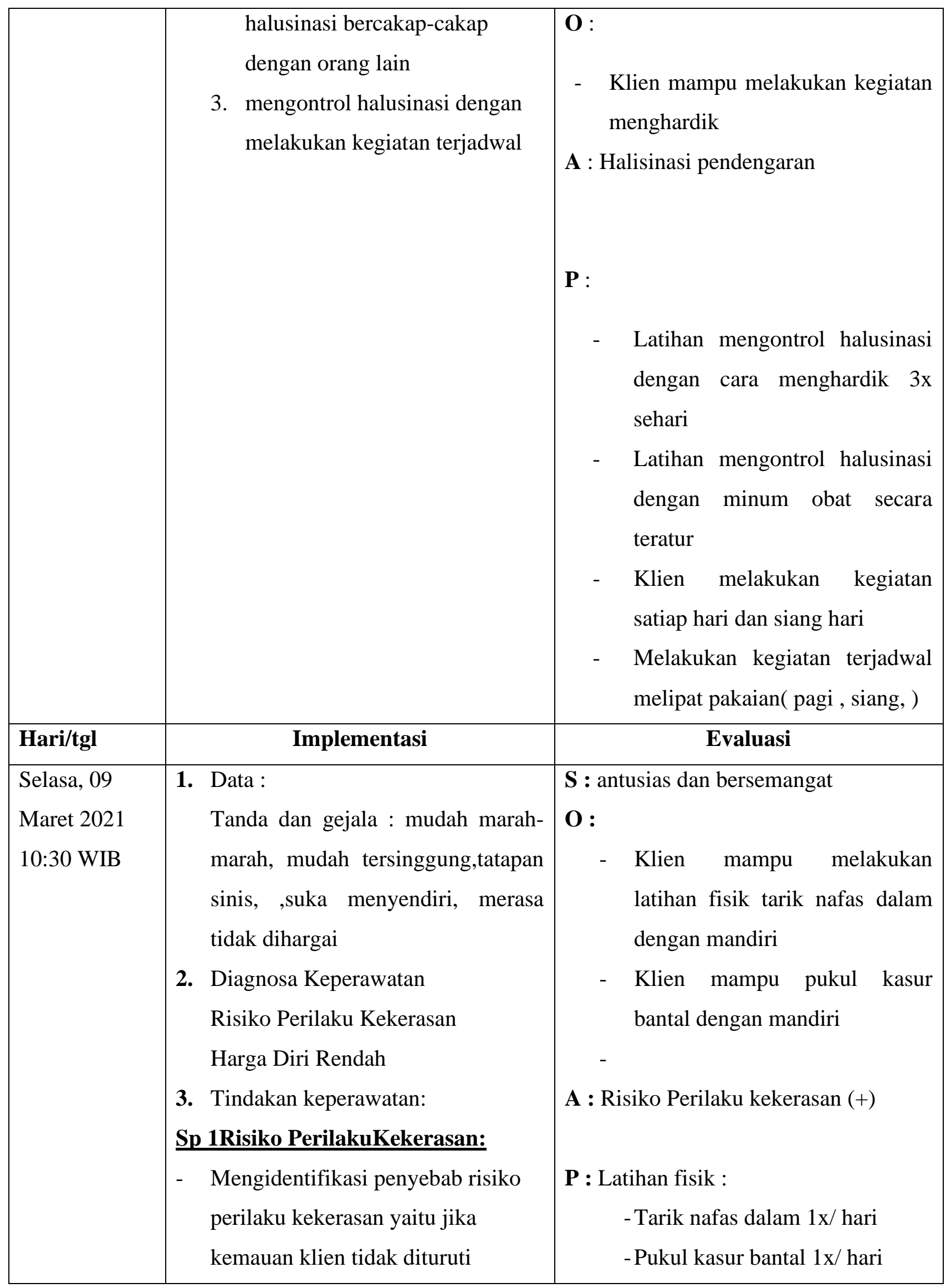




\begin{tabular}{|c|c|c|}
\hline & $\begin{array}{l}\text { - Mengidentifikasi tanda dan gejala } \\
\text { risiko perilaku kekerasan yaitu } \\
\text { klien marah, mengamuk tanpa } \\
\text { jelas, merusak barang-barang, dan } \\
\text { cenderung melukai orang lain } \\
\text { - Menyebutkan cara mengontrol } \\
\text { risiko perilaku kekerasan adalah } \\
\text { dengan latihan fisik } 1 \text { : tarik napas } \\
\text { dalam latihan fisik } 2 \text { : pukul kasur } \\
\text { bantal } \\
\text { Membantu klien latihan tarik napas } \\
\text { dalam dan pukul kasur bantal. } \\
\text { 4. RTL: } \\
\text { Sp2 Risiko Perilaku Kekerasan: } \\
\text { Mengontrolrisiko perilaku } \\
\text { kekerasan dengan minum obat } \\
\text { secara teratur }\end{array}$ & \\
\hline $\begin{array}{l}\text { Rabu, } 10 \\
\text { Maret } 2021 \\
\text { 10:00 WIB }\end{array}$ & $\begin{array}{l}\text { 1. Data: } \\
\text { Tanda dan gejala : mudah marah- } \\
\text { marah, mudah tersinggung,tatapan } \\
\text { sinis, merasa tidak dihargai } \\
\text { Kemampuan : berjualan depan } \\
\text { rumah } \\
\text { 2. Diagnosa Keperawatan } \\
\text { Risiko Perilaku Kekerasan } \\
\text { Harga Diri Rendah } \\
\text { 3. Tindakan keperawatan: } \\
\text { Sp 2Risiko Perilaku Kekerasan } \\
\text { 1. Mengevaluasi kemampuan } \\
\text { klienuntuk tarik nafas dalam } \\
\text { dan pukul kasur bantal }\end{array}$ & $\begin{array}{ll}\text { S : } & \text { senang dan antusias } \\
\text { O : } & \\
- & \text { Klien mampu melakukan tarik } \\
& \text { nafas dalam dengan mandiri } \\
- & \text { Klin mampu pukul kasur bantal } \\
& \text { secara mandiri } \\
- & \text { Klien mampu ke poli jika } \\
& \text { merasa kumat dan meminum } \\
& \text { obat secara teratur dengan } \\
& \text { bantuan perawat } \\
\text { A : } & \text { Risiko Perilaku kekerasan }(+) \\
\text { P : } & \end{array}$ \\
\hline
\end{tabular}




\begin{tabular}{|c|c|c|}
\hline & $\begin{array}{l}\text { 2. Memberikan informasi tentang } \\
\text { penggunaan obat } \\
\text { 4.RTL: } \\
\text { Sp } 3 \text { Risiko Perilaku Kekerasan } \\
\text { - Komunikasi secara } \\
\text { verbal:Asertif/bicara baik-baik. }\end{array}$ & $\begin{array}{ll}\text { - } & \text { Latihantarik nafas dalam } 1 \\
\text { x/hari } \\
\text { - } \quad \text { Latihan pukul kasur bantal } 1 \\
\text { x/hari } \\
\text { - } \\
\text { Minum Obat }\end{array}$ \\
\hline $\begin{array}{l}\text { Jumat, } 12 \\
\text { Maret } 2021 \\
\text { 10:30 WIB }\end{array}$ & $\begin{array}{l}\text { 1. Data: } \\
\text { Tanda dan gejala : mudah marah- } \\
\text { marah, mudah tersinggung,tatapan } \\
\text { sinis, merasa tidak dihargai } \\
\text { Kemampuan : berjualan } \\
\text { 2. Diagnosa Keperawatan: } \\
\text { Risiko Perilaku Kekerasan } \\
\text { Harga Diri Rendah } \\
\text { 3. Tindakan keperawatan: } \\
\text { Sp 3Risiko Perilaku Kekerasan } \\
\text { Mengevaluasi kemampuan klien } \\
\text { untuk tarik nafas dalam dan pukul } \\
\text { kasur bantal } \\
\text { Minum obat } \\
\text { Komunikasi secara verbal : } \\
\text { asertif/bicara baik-baik } \\
\text { 4.RTL: }\end{array}$ & 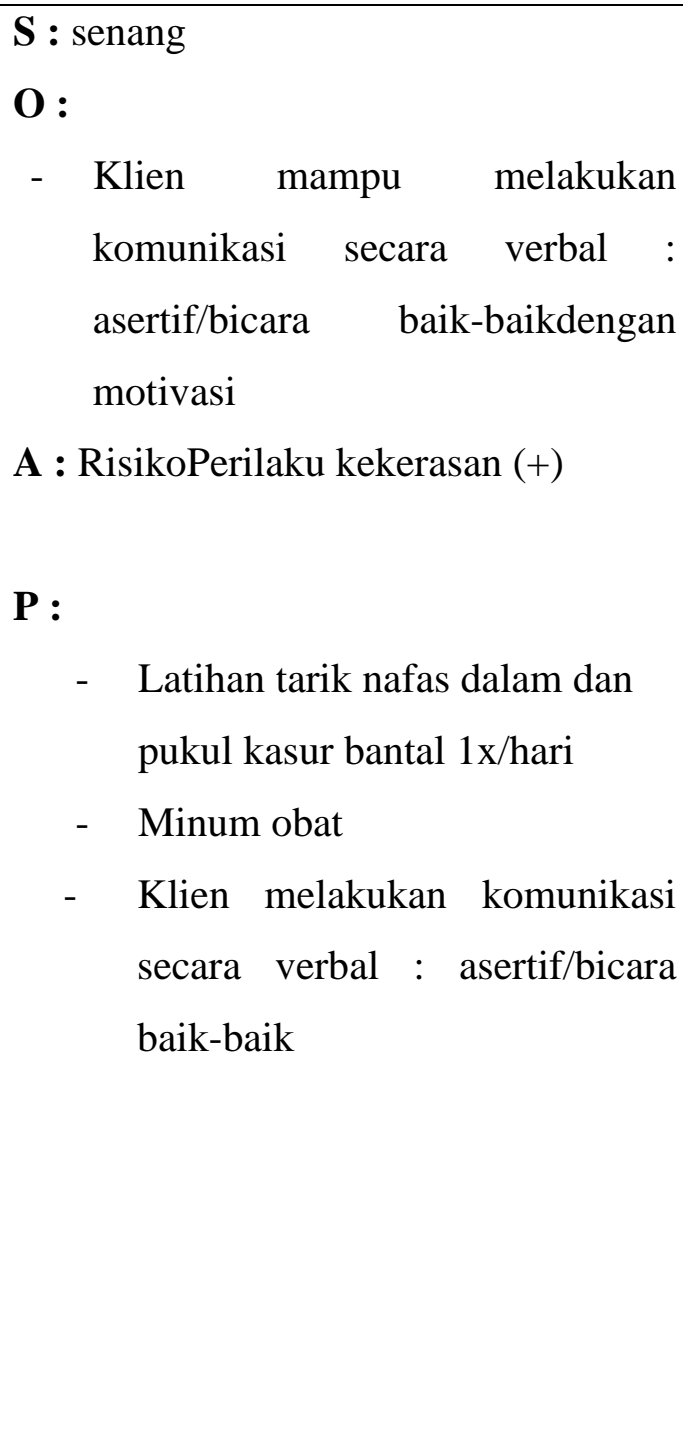 \\
\hline $\begin{array}{l}\text { Sabtu, } \\
13 \text { Maret } \\
2021 \\
10: 30 \text { WIB }\end{array}$ & $\begin{array}{l}\text { 1. Data: } \\
\text { Tanda dan gejala : mudah marah- } \\
\text { marah, mudah tersinggung,tatapan } \\
\text { sinis, merasa tidak dihargai }\end{array}$ & $\begin{array}{l}\text { S : } \\
\text { O : } \\
\\
\quad \text { Klien mang } \\
\quad \text { kegiatan ibadah dengan baik }\end{array}$ \\
\hline
\end{tabular}




\begin{tabular}{|l|l|l|}
\hline Kemampuan : berjualan & \multicolumn{1}{c|}{ misalnya Sholat } \\
2. $\begin{array}{l}\text { Diagnosa Keperawatan: } \\
\text { Risiko Perilaku Kekerasan } \\
\text { Harga Diri Rendah }\end{array}$ & A : Risiko perilaku kekerasan (+) \\
3. Tindakan keperawatan: & P: \\
Sp 4Risiko Perilaku Kekerasan & - & Latihan tarik nafas dalam dan \\
- Mengevaluasi kemampuan klien & - & Mukul kasur bantal 2x/hari \\
dalam tarik nafas dalam dan pukul & - & Latihan melakukan komunikasi \\
kasur bantal, minum obat secara & secara verbal : asertif/bicara \\
teratur dan bicara baik-baik. & baik-baik \\
Melatih klien untuk melaksanakan & - & Latihan klien untuk \\
kegiatan spiritual yang sudah & melaksanakan kegiatan spiritual \\
diatur. & yang sudah diatur. \\
RTL : &
\end{tabular}




\section{BAB 4}

\section{DISKUSI DAN PEMBAHASAN}

Satelah penulis melaksanakan asuhan keperawatan kepada Ny.P dengan Halusinasi Pendengaran di Yayasan Pemenang Jiwa Sumatera maka penulis pada $\mathrm{BAB}$ ini akan membahasan kesenjangan antara teoritis dengan tinjauan kasus. Pembahasan dimulai melalui tahapan proses keperawatan yaitu pengkajian, diagnosa keperawatan, perencanaan, pelaksanaan dan evaluasi.

\subsection{Tahap Pengkajian}

Selama pengkajian dilakukan pengumpulan data dari beberapa sumber, yaitu dari pasien dan tatangga sekitar. Maka penulis melakukan pendekatan kepada pasien melalui komunikasi teraupatik yang lebih terbuka membantu klien untuk memecahkan perasaannya dan juga melakukan observasi kepada pasien. Menurut Andri at al, (2019). Adapun upaya tersebut yaitu:

1. Melakukan pendekatan dan membina hubungan saling percaya diri pada klien agar klien lebih terbuka dan lebih percaya dengan menggunakan perasaan.

2. Mengadakan pengkajian klien dengan wawancara Dalam pengkajian ini, penulis tidak menemukan kesenjangan karena ditemukan hal sama seperti: diteori: Halusinasi adalah suatu gejala gangguan jiwa pada individu yang ditandai dengan perubahan sensori persepsi; merasakan sensasi palsu berupa suara, penglihatan, pengecapan, perabaan dan penghiduan. Pasien merasakan stimulus yang sebenarnya tidak ada. Perawat harus jeli dalam melakukan pengkajian untuk menggali penyebab perilaku dilakukan selama dirumah (Mare, 2021).

\subsection{Tahap perencanaan}

Perencanaan dalam proses keperawatan lebih dikenal dengan rencana asuhan keperawatan yang merupakan tahap selanjutnya satelah pangkajian dan penentuan diagnosa keperawatan. Pada tahap perencanaan penulis hanya menyusun rencana tindakan keperawatan sesuai dengan pohon masalah keperawatan yaitu : Halusinasi Pendengaran. 
Pada tahap ini antara tinjauan teoritis dan tinjaun kasus tidak ada kesenjangan sehingga penulis dapat melaksanakan tindakan seoptimal mungkin dan didukung dengan seringnya bimbingan dengan pembimbing. Secara teoritis digunakan cara strategi pertemuan sesuai dengan diagnosa keperawatan yang muncul saat pengkajian. Adapun upaya yang dilakukan penulis yaitu :

a. Mengidentifikasi isi, frekuensi, waktu terjadi, situasi pencatus, perasaan dan respon halusinasi

b. Mengontrol halusinasi dengan Mneghardik

c. Mengoontrol halusinasi dengan minum obat secara teratur

d. Mengontrol halusinasi dengan bercakap-cakap dengan orang lain

e. Mengontrol halusinasi dengan kegiatan terjadwal

\subsection{Tahap Implementasi}

Pada tahap implementasi, penulis hanya mengatasi 1 masalah keperawatan yakni: diagnosa keperawatan Halusinasi Pendengaran di karenakan masalah utama yang dialami klien. Pada diagnosa keperawatan Halusinasi Pendengaran strategi pertemuan yaitu mengidentifikasi isi, frekuensi, waktu terjadi, situasi pencatus, perasaan dan respon halusinasi, Mengontrol halusinasi dengan Menghardik Strategi pertemuan yang kedua yaitu mengontrol halusinasi dengan minum obat secara teratur strategi pertemuan katiga yaitu mengontrol halusinasi dengan bercakap-cakap dengan lain strategi pertemuan ke empat yaitu mengontrol halusinasi dengan melakukan kegiatan terjadwal (Libriatanti, 2019).

\subsection{Tahap Evaluasi}

Pada tinjauan teoritis evaluasi yang diharapkan adalah :

1. Pasien mempercayai perawat sebagai terapis

2. Dapat mengidentifikasi dan mengontrol Halusinasi

3. Dapat mengendalikan Halusinasi dengan menghardik

4. Dapat mengendalikan Halusinasi dengan cara minum obat secara teratur

5. Dapat mengendalikan Halusinasi dengan bercakap-cakap dengan orang lain.

6. Dapat mengendalikan Halusinasi dengan melakukan kegiatan terjadwal. 
Pada tinjauan kasus evaluasi yang dihasilkan adalah :

1. Klien sudah dapat mengontrol dan mengidentifikasi Halusinasi

2. Klien dapat mengendalikan halusinasi dengan Menghardik

3. Klien dapat mengendalikan Halusinasi dengan cara minum obat secara teratur

4. Klien dapat mengendalikan halusinasi dengan bercakap-cakap dengan orang lain

5. Klien dapat mengendalikan halusinasi dengan melakukan kegiatan terjadwal. 


\section{BAB 5}

\section{PENUTUP}

\subsection{Kesimpulan}

Satelah menguraikan tentang proses keperawatan pada Ny.P penulis melanjutkan asuhan keperawatan pada klien dengan Halusinasi di Yayasan Pemenang Jiwa Medan, Maka penulis mengambil kesimpulan untuk meningkatkan mutu asuhan keperawatan yang telah ada:

1. Dalam melakukan asuhan keperawatan pada klien dengan kasus Halusinasi dilakukan meliputi aspek psikososial, spiritual dan melibatkan keluarga didalamnya.

2. Dalam melakukan asuhan keperawatan maka antar perawat dan klien harus membina hubungan saling percaya.

3. Bagi mahasiswa/mahasiswi agar lebih memperdalam ilmu pengatahuan khususnya tentang keperawatan jiwa.

4. Bagi klien agar dapat berkomunikasi dan berinteraksi dengan baik serta klien mengikuti pengobatan secara optimal sampai berhasil agar tidak terulang kembali.

5. Peran serta keluarga sangat penting dalam penyembuhan klien karena dengan dukungan keluarga penyembuhan klien dapat tercapai sesuai dengan yang diharapkan.

\subsection{Saran}

Diharapkan pada keluarga agar selalu memberikan dukungan kepada klien karena dukungan dapat memberikan efek yang lebih baik terhadap psikis dan kesehatan pasien. 


\section{DAFTAR PUSTAKA}

Aji, W. M. H. (2019). Asuhan Keperawatan Orang Dengan Gangguan Jiwa Halusinasi Dengar Dalam Mengontrol Halusinasi.10.31219/osf.io/n9dgs

Aldam, S. F. S., \& Wardani, I. Y. (2019).Efektifitas penerapan standar asuhan keperawatan jiwa generalis pada pasien skizofrenia dalam menurunkan gejala halusinasi. Jurnal Keperawatan Jiwa, 7(2), 165172.https://doi.org/10.26714/jkj.7.2.2019.167-174

Andri, J., Febriawati, H., Panzilion, P., Sari, S. N., \& Utama, D. A. (2019). Implementasi keperawatan dengan pengendalian diri klien halusinasi pada pasien skizofrenia. Jurnal Kesmas Asclepius, 1(2), 146155.https://doi.org/10.31539/jka.v1i2.922

Anjar, A. (2018). Asuhan Keperawatan Jiwa Dengan Masalah Utama Gangguan Persepsi Sensori: Halusinasi Pendengaran Pada Tn. N Dengan Diagnosa Medis Skizofrenia Di Ruang Iv B Rumkital Dr. Ramelan Surabaya (Doctoral dissertation, stikes hang tuah surabaya).

Astutik, D. (2018). Terapi Aktivitas: Menulis Kalimat Istighfar Terhadap Perubahan Gejala Halusinasi Pendengaran Pada Pasien Skizofrenia Rsjd Dr. Amino Gondhohutomo Provinsi Jawa Tengah (Doctoral dissertation, Universitas Muhammadiyah Semarang).

Hafizuddin, D. T. M. (2021). Mental Nursing Care on Mr. A With Hearing Hallucination Problems. https://doi.org/10.31219/osf.io/r3pqu

Pardede, J.A, Irwan, F., Hulu, E. P., Manalu, L. W., Sitanggang, R., \& Waruwu, J. F. P. (2021).Asuhan keperawatan Jiwa Dengan Masalah Halusinasi. https://doi.org/10.31219/osf.io/fdqzn

Keliat B,. (2014). Proses Keperawatan Jiwa Edisi II. Jakarta : EGC.

Libriatanti, S. R. (2019). Nursing Care Modality Therapy (Gymnstics Therapy) On ODGJ Who Experienced Hallucinations At Mental Health Services: Pospa Siwa Blitar City.DOI : 10.31219/osf.io/2xwsv

Mare, M. N. S. (2021, March 24). Application of Mental Nursing Care on Ny. T With Risk of Violent Behavior At Pemenangan Jiwa Sumatera Foundation. https://doi.org/10.31219/osf.io/ypmu6

Pardede, J. A. (2019). The Effects Acceptance and Aommitment Therapy and Health Education Adherence to Symptoms, Ability to Accept and Commit to Treatment and Compliance in Hallucinations Clients Mental Hospital of Medan, North Sumatra. J Psychol Psychiatry Stud, 1, 30-35.

Pardede, J. A., \& Purba, J. M. (2020). Family Support Related to Quality of Life on Schizophrenia Patients. Jurnal Ilmiah Permas: Jurnal Ilmiah STIKES Kendal, 10(4), 645-654.https://doi.org/10.32583/pskm.v10i4.942 
Pardede, J. A., Simanjuntak, G. V., \& Laia, R. (2020). The Symptoms of Risk of Violence Behavior Decline after Given Prgressive Muscle Relaxation Therapy on Schizophrenia Patients. Jurnal Ilmu Keperawatan Jiwa, 3(2), 91-100.http://dx.doi.org/10.32584/jikj.v3i2.534

Pardede, J. A., \& Siregar, R. A. (2016). Pendidikan Kesehatan Kepatuhan Minum Obat Terhadap Perubahan Gejala Halusinasi Pada Klienskizofrenia. Mental Health, 3(1).

Rinawati, F., \& Alimansur, M. (2016). Analisa faktor-faktor penyebab gangguan jiwa menggunakan pendekatan model adaptasi stres stuart. Jurnal ilmu kesehatan, 5(1), 34-38.https://doi.org/10.32831/jik.v5i1.112

Telles-Correia, D., Moreira, A. L., \& Gonçalves, J. S. (2015).Hallucinations and related concepts - their conceptual background.Frontiers in psychology, 6, 991.https://doi.org/10.3389/fpsyg.2015.00991

Widuri, N. R., \& Widodo, A. (2016). Upaya Penurunan Intensitas Halusinasi Dengan Cara Mengontrol Halusinasi Di Rsjd Arif Zainudin Surakarta (Doctoral dissertation, Universitas Muhammadiyah Surakarta).

Yusuf, A. (2015). Buku Ajar Keperawatan Kesehatan Jiwa. Jakarta: Salemba Medika

Zelika, A. A., \& Dermawan, D. (2015). Kajian Asuhan Keperawatan Jiwa Halusinasi Pendengaran Pada Sdr. D Di Ruang Nakula RSJD Surakarta. Profesi (Profesional Islam): Media Publikasi Penelitian, 12(02).http://dx.doi.org/10.26576/profesi.87 